4. Understanding The Cosmetics Regulation. URL: https://cosmeticseurope.eu/cosmetics-industry/understanding-cosmeticsregulation/ (дата звернення: 01.09.2020).

5. Regulation (EC) No 1223/2009. (2009). European parliament and of the council of 30 November 2009 on cosmetic products. Official Journal of the European Union. P. L 342/59- L 342/209.

6. Український ринок парфумерно-косметичної продукції // Асоціація «Парфумерія та косметика України». URL: http://apcu.ua/rinkovidoslidzhennya-ta-statistichni-dani/parfumernokosmetichnij-rinok-ukraini.htm (дата звернення 01.09.2020).

7. Регулювання косметичної продукції в Україні: оприлюднено доопрацьовану постанову. URL: https://www.apteka.ua/article/530929 (дата звернення: 07.11.2020).

8. Казакова І.С., Лебединець В.О. Аналіз та визначення перспектив розвитку ринку лікарських косметичних косметичних засобів в Україні. Сочіальна фармація в охороні здоров'я. 2020. Т. 6. № 2. С.44-60.

DOI https://doi.org/10.30525/978-9934-26-006-3-31

\title{
ОСОБЛИВОСТІ ЕКСПРЕСІЇ ТРАНСКРИПЦІЙНИХ ФАКТОРІВ TWIST I SNAIL В КАРЦИНОМАХ ЕНДОМЕТРІЮ ХВОРИХ З І-ІІ ТА ІІІ СТАДІЕЮ ПУХЛИННОГО ПРОЦЕСУ
}

\author{
Марченко I. O. \\ аспірантка лабораторії генетики раку
}

Інститут експериментальної патології, онкології і радіобіології імені Р. Є. Кавецького Національної академії наук Украӥни

Несіна І. П.

кандидат біологічних наук, старший науковий співробітник лабораторії генетики раку Інститут експериментальної патологї̈, онкології і радіобіології імені Р. С. Кавецького Начіональної академії наук Украӥни м. Київ, Украӥна

На сьогодні добре відомо, що основною причиною загибелі онкологічного хворого $є$ метастазування злоякісної пухлини, яке $\epsilon$ результатом втрати генетичного контролю над процесами диференціювання, проліферації та апоптозу [1, с. 1]. Однією з причин 124 
пухлинної інвазії і метастазування автори вбачають в реактивації при неопластичній прогресії такого ключового процесу ембріогенезу, як епітеліально-мезенхімальний перехід (ЕМП), виникнення якого при онкогенезі може відбуватися при активації декількох сигнальних шляхів різними позаклітинними імпульсами, у тому числі, такими багатофункціональними транскрипційними факторами, як Twist, Snail, Slug i Zeb1 [1, c. 248; 2, c. R86].

Зокрема було встановлено, що Twist i Snail сприяють метастатичному розповсюдженню епітеліальних клітин, зв'язуючись 3 промотором гена CDH1 (Е-кадгерину) i пригнічуючи його транскрипцію, що зумовлює активацію $\mathrm{Wnt} / \beta$-катенінового шляху, послаблення міжклітинних контактів і набування раковими клітинами мезенхімальних властивостей [2, с. R86; 3, с. 821; 4, c. 3 ].

Зазначені процеси відбуваються i при прогресії карцином ендометрію - одного з найбільш поширених гінекологічних злоякісних новоутворень жінок в Україні і світі. [5, с. 10], Проте, питання щодо ролі ЕМП у формуванні певного інвазивного потенціалу в злоякісних пухлинах ендометрію вивчені недостатньо. До цього часу не відомо, які молекулярні перебудови і типи інвазії привалюють на пізніх стадіях прогресії ЕКЕ.

Враховуючи зазначене, мета роботи полягала у вивченні зв'язків між експресією транскрипційних факторів Twist i Snail в карциномі ендометрію і показниками прогресування пухлинного процесу у хворих з I-II та III стадією захворювання.

Матеріал дослідження. Зразки операційного матеріалу 45 хворих на ендометріїдну карциному ендометрію (ЕКЕ) у віці від 32 до 78 років (середній вік 59,8 2 ,1 років), які не отримували передопераційного лікування. Переважна більшість хворих 33 (73,3\%) характеризувались I-II стадією пухлинного процесу і 12 (26,7\%) хворих мали метастази у регіонарні лімфатичні вузли і III стадію захворювання, Усі хворі перебували на лікуванні у відділенні онкогінекології Національного інституту раку МО3 України в період 2014 по 2018 р., не отримували передопераційної терапії і дали інформовану згоду на використання їх біологічного матеріалу для проведення наукових досліджень. Під час дослідження були дотримані усі необхідні етичні стандарти відповідно до вимог загальновизнаних міжнародних правил у рамках Гельсінської декларації 2008 року. Методи дослідження: клінічний, морфологічний, імуногістохімічний (ІГХ), статистичний.

IГХ виявлення біомолекулярних маркерів здійснювали на депарафінованих зрізах пухлин ендометрію, 3 використанням 
поліклонального антитіла Twist1/Twist2 фірми «Thermo Fisher Scientific», США, каталожний №PA5-78211 і моноклонального антитіла Anti-Hu Snail1, клон 20С8 , фірми «Invitrogen», США. Результати IГХ реакції оцінювали напівкількісним методом, аналізуючи у кожному препараті по 700-1000 клітин i, шляхом підрахунку кількості забарвлених клітин з ядерною локалізацією маркерів, визначали індекс мітки (IM, \%). Експресію маркерів вважали позитивною при IM>1,0\%. Отримані дані порівнювали 3 результатами наших попередніх досліджень, в яких визначали експресію маркерів ЕМП у цих самих випадках ЕKE [6, с. 219].

Результати дослідження. При морфологічному аналізі новоутворень (забарвлення гематоксиліном та еозином) встановлено, що досліджені пухлини були ЕКЕ різного ступеня диференціювання: 24 випадки (53,3\%) помірного (G2) i 21 випадок (46,7\%) низького ступеня диференціювання (G3). У 18 (40,0\%) хворих спостерігались пухлини, що інвазували $<1 / 2$ міометрію і у 27 (60,0\%) випадків - пухлини 3 глибокою (>1/2) інвазією міометрію.

Результати ІГХ дослідження показали, що позитивна експресія транскрипційного фактора Twist виявлялась у 55,3\% i Snail y 37,8\%

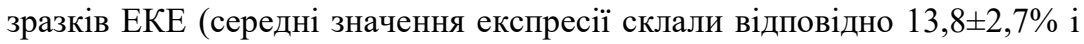
$5,4 \pm 1,6 \%$ ).

Визначено, що позитивна експресія обох факторів транскрипції асоціювалась зі зниженою експресією Е-кадгерину i $\beta$-катенину i достовірним підвищенням експресії віментину порівняно 3 цими показниками у ЕКЕ з негативною експресією Twist i Snail (табл. 1).

Таблиця 1

Зіставлення експресії маркерів ЕМП у пухлинних клітинах ендометрію в залежності від експресії транскрипційних факторів Twist i Snail

\begin{tabular}{|c|c|c|c|c|}
\hline \multirow{3}{*}{$\begin{array}{l}\text { Молекулярні } \\
\text { маркери ЕМП }\end{array}$} & \multicolumn{4}{|c|}{ Середні значення експресії маркерів ЕМП, М $\pm \mathbf{m}, \%$} \\
\hline & \multicolumn{2}{|c|}{ Twist } & \multicolumn{2}{|c|}{ Snail } \\
\hline & позитивна & негативна & позитивна & негативна \\
\hline Е-кадгерин & $44,3 \pm 3,8$ & $61,4 \pm 4,7 *$ & $57,8 \pm 4,1$ & $65,9 \pm 4,8$ \\
\hline$\beta$-катенін & $78,6 \pm 4,2$ & $86,3 \pm 5,4$ & $79,5 \pm 4,9$ & $87,8 \pm 5,1$ \\
\hline віментин & $33,9 \pm 3,4$ & $14,6 \pm 3,1 *$ & $37,7 \pm 3,9$ & $22,8 \pm 2,9 * *$ \\
\hline
\end{tabular}
пухлинах з позитивною експресією Twist; ** $-p<0,05$ порівняно з експресією відповідного маркера у пухлинах з позитивною експресією Snail. 
Отримані дані свідчать про існування взаємодії Twist i Snail 3 іншими білками, що беруть участь у перетворенні епітетеліальних пухлинних клітин ендометрію на клітини з мезенхімальними ознаками. Поряд 3 цим, було виявлено різну спрямованість експресії Twist i Snail в залежності від таких показників, як ступінь диференціювання i глибина інвазії пухлини у міометрій. Було встановлено, що у пухлинах 3 низьким ступенем диференціювання і глибокою інвазією пухлини у міометрій експресія Twist дещо (на рівні тенденціï) підвищувалась

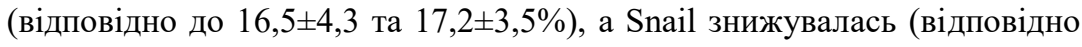
до $4,7 \pm 1,9$ та $4,4 \pm 1,8 \%$ ) порівняно 3 показниками у G2-пухлинах (відповідно $13,1 \pm 3,3$ та $14,1 \pm 3,9 \%$ ), і 3 інвазією $<1 / 2$ міометрію

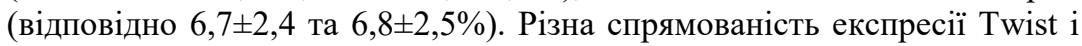
Snail може свідчити про те, що в EKE, як і в деяких злоякісних новоутвореннях іншого генезу, експресія Snail, є ознакою початкових стадій ЕMП [2, с. R88; 7, c. 87], а підвищення експресії Twist пов’язують 3 прогресуванням пухлинного процесу [7, с. 88].

Проте, низкою авторів було доведено, що пухлинні клітини, хоча i набувають мезенхімальних ознак, проте i не втрачають свої епітеліальні властивості назавжди i можуть існувати як у епітеліальному, мезенхімальному, так і гібридному фенотипах, що підвищує їх потенцію до утворення метастазів [4, с. 2]. На наш погляд саме цим можна пояснити отримані нами дані про значне зниження експресії Twist у пухлинах хворих 3 III стадією пухлинного процесу (до $1,8 \pm 0,3 \%$ ) порівняно з експресією цього маркера у пухлинах хворих з I-II стадією $(16,7 \pm 2,8 \%, \mathrm{p}<0,01)$.

Поряд 3 цим, було встановлено, що пухлини хворих 3 I-II стадією захворювання, з високою експресією Twist набували морфологічного фенотипу, характерного для мезенхімальних клітин, а саме відзначалися скупченням досить мономорфних гістіоцитоподібних клітин із гіперхромними ядрами, На відміну від цього, пухлини хворих з III стадією пухлинного процесу, які у 62,5\% випадків мали негативну експресію Twist, характеризувались іншим характером інвазивного росту, головною ознакою якого була інвазія міометрію великими безструктурними угрупуваннями пухлинних клітин у вигляді солідних осередків та тяжів, що є морфологічним проявом колективної міграції.

Таким чином, проведене дослідження дозволило виявити зв'язок між молекулярним фенотипом за експресією маркерів ЕMП Twist i Snail в EKE i морфологічними особливостями карцином ендометрію. На підставі отриманих результатів можна припустити, що інвазування карцином ендометрію у міометрій на початкових етапах розвитку цієї 
форми раку відбувається за участю ЕМП, а при подальшому прогресуванні пухлини, завдяки пластичності ЕМП [4, с. 4], можуть відбуватися зворотні процеси, які призводять до відновлення міжклітинних контактів i більш активній - колективній міграція пухлинних клітин у міометрій і метастазуванні у регіонарні лімфатичні вузли і віддалені органи.

\section{Література:}

1. Jinesh G.G., Broh A.S. The genetic script of metastasi. Biological Reviews. 2020. Vol. 95. P. 244-266. Doi:10.1111/brv.12562

2. Makker A., Goel M.M. Tumor progression, metastasis, and modulators of epithelial-mesenchymal transition in endometrioid endometrial carcinoma: an update. Endocrine-Related Cancer. 2016. Vol. 23, №2. P. 85-111. Doi:10.1530/ERC-15-0218

3. Xie X., Zheng X., Wang J., Chen L. Clinical significance of Twist, E-cadherin, and $\mathrm{N}$-cadherin protein expression in endometrioid adenocarcinoma. Journal of Cancer Research and Therapeutics. 2017. Vol. 13. P. 817-822. Doi: 10.4103/jcrt.JCRT_405_17

4. Bhatia S., Wang P., Toh A., Thompson E.W. New insights into the role of phenotypic plasticity and EMT in driving cancer progression. Frontiers Molecular Biosciences. 2020. Doi: 10.3389/fmolb.2020.00071

5. «Рак в Україні, 2018-2019»: Бюлетень Національного канцерреєстру України № 21 / Федоренко 3.П., Гулак Л., Михайлович Ю., та ін.; за ред. Колеснік О.О. Київ, 2020. 102 с.

6. Nesina I.P., Iurchenko N.P., Buchynska L.G. Markers of the epithelial-mesenchymal transition in cells of endometrial carcinoma. Exptrimental Oncology. 2018. Vol. 40, № 3. P. 218-222.

7. Крахмаль НВ, Завьялова МВ, Савельева ОЕ. и др. Морфологические и молекулярно-генетические проявления опухолевой инвазии при раке молочной железы: монография / под ред. B.M. Перельмутера, М.В. Завьяловой. Томск: Изд-во Томского университета, 2017. $128 \mathrm{c}$. 